\title{
Disorders of Androgen Synthesis - from Cholesterol to Dehydroepiandrosterone
}

\author{
Walter L. Miller \\ Department of Pediatrics, University of California, San Francisco, Calif., USA
}

\begin{abstract}
Key Words
P450c17 · Dehydroepiandrosterone $\cdot$ Polycystic ovary syndrome $\cdot$ Adrenarche $\cdot$ Steroidogenic acute regulatory protein $\cdot$ Steroids $\cdot$ P450 oxidoreductase $\cdot$ Hormones - Antley-Bixler syndrome $\cdot$ Congenital lipoid adrenal hyperplasia
\end{abstract}

\begin{abstract}
Androgens and estrogens are primarily made from dehydroepiandrosterone (DHEA), which is made from cholesterol via four steps. First, cholesterol enters the mitochondria with the assistance of the steroidogenic acute regulatory protein (StAR). Mutations in the StAR gene cause congenital lipoid adrenal hyperplasia (lipoid CAH), a potentially lethal disease in which virtually no steroids are made. Lipoid CAH is common among Palestinian Arabs and people from eastern Arabia, and among Korean and Japanese people. Second, within the mitochondria, cholesterol is converted to pregnenolone by the cholesterol side chain cleavage enzyme, P450scc; disorder of this enzyme is very rare, probably due to embryonic lethality. Third, pregnenolone undergoes $17 \alpha$-hydroxylation by microsomal P450c17. 17 $\alpha$-Hydroxylase deficiency, manifesting as female sexual infantilism and hypertension, is rare except in Brazil. Finally, 17-OH pregnenolone is converted to DHEA by the 17,20 lyase activity of P450c17. The ratio of the 17,20 lyase to $17 \alpha-$ hydroxylase activity of $\mathrm{P} 450 \mathrm{c} 17$ determines the ratio of
\end{abstract}

C21 to C19 steroids produced. This ratio is regulated posttranslationally by at least three factors: the abundance of the electron-donating protein P450 oxidoreductase (POR), the presence of cytochrome $b_{5}$ and the serine phosphorylation of P450c17. Mutations of POR are a new, recently described disorder manifesting as the Antley-Bixler skeletal dysplasia syndrome, and a form of polycystic ovary syndrome.

Copyright (c) 2005 S. Karger AG, Basel

\section{Steroid Hormones}

Steroid hormones are essential for life and reproduction. There are several classes of steroid hormones, defined according to their physiologic actions and the receptors to which they bind. Mineralocorticoids instruct the kidney to retain sodium. In the absence of mineralocorticoids, the kidney discards $\mathrm{Na}^{+}$and retains $\mathrm{K}^{+}$and $\mathrm{H}^{+}$, leading to hyponatremia, hyperkalemia, acidosis, dehydration and death. Thus, mineralocorticoids play a central role in salt and water metabolism and in regulating blood pressure [1]. Glucocorticoids help to maintain euglycemia, mediate stress responses and regulate a variety of immune responses. Survival is possible in the absence of glucocorticoids (Addison's disease) until the time of severe physiologic stress (febrile illness, major surgery, hypovolemia) [2]. Three distinct classes of sex steroids are required for sexual differentiation and repro-

\section{KARGER \\ Fax +4161306 1234 E-Mail karger@karger.ch} www.karger.com 
duction: progestins are required for normal menstrual cycles and for the maintenance of pregnancy; estrogens for female sexual development and reproduction; and androgens for male sexual differentiation in fetal life, male sexual development, and reproduction. While the individual can survive without sex steroids, their loss would eventually be lethal to the species. Thus, steroid hormones play a central, crucial and irreplaceable role in human life.

\section{Mitochondria, Steroidogenic Acute Regulatory Protein and P450scc}

The first, rate-limiting and hormonally regulated step in the biosynthesis of all steroid hormones is the conversion of cholesterol to pregnenolone, described in the next paragraph. Steroidogenic cells do not store significant quantities of steroid hormones; hence steroid secretion is directly related to steroid synthesis. Steroid synthesis is regulated both acutely and chronically. The acute stimulation of steroidogenesis, as in the rapid rise in cortisol in response to intravenous administration of $\mathrm{ACTH}$, is mediated at the level of cholesterol import into mitochondria, which is facilitated by the steroidogenic acute regulatory protein (StAR) [3, 4]. Chronic stimulation, over a period of hours to weeks, such as in the hypercortisolism of Cushing's disease, is mediated by increased transcription of the genes encoding the various steroidogenic enzymes. Thus, the acutely regulated step is the availability of substrate to, and the chronically regulated step is the amount of, those enzymes.

The conversion of cholesterol to pregnenolone is accomplished by the cleavage of the cholesterol side chain, catalyzed by a mitochondrial cytochrome P450 enzyme termed P450scc, where scc designates side chain cleavage. This single enzyme, encoded by a single gene $[5,6]$ (sometimes termed CYP11A) on chromosome 15q23-q24 [7], catalyzes three distinct sequential reactions on a single active site: cholesterol sequentially undergoes 20-hydroxylation, 22-hydroxylation, and scission of the 20,22 carboncarbon bond to yield pregnenolone and isocaproaldehyde [8]. The expression of the gene for P450scc enables a cell to become steroidogenic (able to make steroids). The level of P450scc gene transcription is hormonally regulated by multiple pathways, permitting independent regulation of steroidogenesis in multiple cell types [9-11], and the amount of P450scc mRNA present in a cell directly correlates with its steroidogenic capacity $[12,13]$. Each of the three reactions catalyzed by $\mathrm{P} 450 \mathrm{scc}$ requires a pair of electrons. A flavoprotein (ferredoxin reductase) receives the electrons from NADPH, then passes them to an iron/ sulfur protein (ferredoxin), which in turn passes them to the P450. Ferredoxin reductase and ferredoxin are generic electron transfer proteins that can donate electrons to any of the various mitochondrial P450 enzymes [14-17]. $\mathrm{P} 450$ scc can only function within the mitochondria [18]; hence, delivery of cholesterol to the inner mitochondrial membrane by StAR is a crucial step in steroidogenesis.

Early work showed that ACTH could induce adrenal steroidogenesis very rapidly, and that this induction could be inhibited by cycloheximide or other inhibitors of protein synthesis [19-22], suggesting that a short-lived protein was an essential trigger of the acute response. The responsible protein, StAR, was first identified in rat adrenals and corpus luteum as a phosphoprotein, seen on 2-dimensional gels that appeared rapidly when cells were stimulated with cAMP [23-25]. Stocco's laboratory then cloned the mouse cDNA and found that expression of StAR in mouse Leydig MA-10 cells increased steroidogenesis 6-fold [26]. StAR similarly increased steroidogenesis in COS-1 cells cotransfected with the P450scc system $[27,28]$, but the definitive proof that StAR is essential in human physiology came from finding StAR mutations in congenital lipoid adrenal hyperplasia (lipoid CAH) [27, 29].

\section{Congenital Lipoid Adrenal Hyperplasia}

Lipoid CAH is a rare autosomal recessive disorder that severely disrupts the synthesis of all adrenal and gonadal steroids [4]. A severe defect in fetal testicular biosynthesis is evident because affected $46, \mathrm{XY}$ genetic males are born with wholly female external genitalia, reflecting an absence of testosterone synthesis between 6 and 12 weeks of gestation. At birth, the adrenals are engorged with cholesterol ester deposits. Affected newborns have low but measurable levels of steroid hormones. They soon die from glucocorticoid and mineralocorticoid deficiency if hormonal replacement therapy is not initiated, but properly treated patients can survive to adulthood [30, 31].

Although StAR is needed for a rapid and maximal steroidogenic response, there are also low levels of StAR-independent steroidogenesis in cells that express StAR [27, 32]. However, some steroidogenic cells, such as those of the placenta [28], do not express StAR. The brain also expresses low levels of StAR in apparently steroidogenic cells that also contain P450scc [33-35], but the role of StAR in the brain is not clear, as there is no known tropic 
Table 1. Lipoid $\mathrm{CAH}$ in Palestinians

\begin{tabular}{lllll}
\hline Nucleotide & Amino acid & Families & Alleles & $\begin{array}{l}\text { Countries of } \\
\text { origin }\end{array}$ \\
\hline A632G & E169G & 1 & 1 & Israel \\
G671T & R182L & 4 & 7 & Denmark, Jordan \\
$\Delta$ C650 & frameshift & 1 & 2 & Kuwait \\
$\Delta 2$ T593 & frameshift & 2 & 3 & Jordan \\
C703T & R193X & 1 & 2 & Israel \\
\hline
\end{tabular}

Seven patients have been reported from 6 families, 1 of which was consanguineous, thus representing 11 unique alleles. Several alleles carried more than 1 mutation, so that the total number of affected alleles is greater than 11. Data are from Bose et al. [32, 43].

stimulus to neurosteroidogenesis [36], and a specific CNS defect in StAR-deficient patients with lipoid CAH has not been reported [36]. The demonstration of StAR-independent steroidogenesis led to formulation of the two-hit model of lipoid CAH [32]. The first hit is the mutation in the StAR gene, ablating StAR-dependent steroidogenesis but permitting StAR-independent steroidogenesis to persist. StAR-independent placental steroidogenesis and placental synthesis of progesterone remain normal, permitting term gestation. Low levels of adrenal StAR-independent steroidogenesis account for the low, but detectable, levels of steroid hormones seen in the sera of lipoid CAH patients in the first month of life [31, 32]. The presence of these steroids appears to explain why untreated lipoid $\mathrm{CAH}$ infants may survive without treatment for several months [31, 32, 37, 45], whereas patients with other forms of salt-wasting $\mathrm{CAH}$ do not. However, these steroid hormone concentrations are too low to suppress secretion of $\mathrm{ACTH}$, gonadotropins and angiotensin II to normal levels. Excess amounts of these tropic hormones stimulate cellular uptake of low-density lipoprotein cholesterol and increased production of cholesterol from acetate. This tropic hormone stimulation results in the accumulation of cholesterol esters, which eventually disrupts the cells, either via physical engorgement of the cell with droplets of cholesterol esters or by a chemical action of cholesterol oxidation products, or both. This second hit thus destroys the low levels of StAR-independent steroidogenesis, leading to the unmeasurable levels of steroid in the serum of older children with lipoid $\mathrm{CAH}$, and to the absence of circulating testosterone in affected 46,XY fetuses [4, 32].

The fetal ovaries do not express the genes for the steroidogenic enzymes and thus do not make steroids [38]; unlike the testes and adrenals, the ovaries only start to make steroid hormones at the onset of puberty. Consequently, the ovaries of 46,XX females affected with lipoid $\mathrm{CAH}$ do not receive the second hit until the onset of puberty, when LH stimulates low levels of StAR-independent steroidogenesis. With each monthly cycle, another follicle is recruited and stimulated by gonadotropins, producing spontaneous age-appropriate breast development in affected 46,XX individuals. However, gonadotropin stimulation quickly results in cholesterol engorgement of these cells (the second hit in lipoid CAH) so that the later phase of ovarian steroidogenesis, the secretion of large amounts of progesterone, does not occur $[39,40]$. Follicles that are not recruited remain unstimulated and constitute a reservoir of steroidogenic cells undamaged by the second hit of lipoid $\mathrm{CAH}$, so that with each monthly cycle a new undamaged follicle is recruited. Estrogen is then produced, leading to cyclic uterine estrogen withdrawal bleeding that resembles normal menses, but, as there is no progesterone, these cycles are anovulatory. The predictions of the two-hit model have recently been confirmed by elegant experiments with StAR knockout mice [41, 42].

StAR mutations causing lipoid $\mathrm{CAH}$ have been described in about 70 patients from all over the world. Lipoid CAH is most common in Japan and Korea [27, 32, $37,43,44]$. The mutation Q258X accounts for about 70\% of affected alleles in Japan and 95\% of the alleles reported to date from Korea. A second population in whom lipoid CAH appears to be common is Palestinian Arabs, among whom 7 cases have been reported to date. However, several different mutations are found in these patients, suggesting founder effects in limited gene pools, and consanguinity (table 1). A third group in whom lipoid $\mathrm{CAH}$ appears to be common is Arabs from the Eastern Province of Saudi Arabia and nearby Qatar, all of whom carry the mutation $\mathrm{R} 182 \mathrm{H}$, suggesting a founder effect [45].

\section{True P450scc Deficiency}

When lipoid CAH was first described, long before the discovery of StAR, it was generally termed '20,22 desmolase deficiency' because it was thought to be a disorder in the enzyme (P450scc) that converts cholesterol to pregnenolone [31]. However, analysis of the gene for P450scc was normal in these patients [46, 47]. Finding StAR mutations in virtually all patients with the lipoid CAH phenotype thus posed the question: 'Why do we not see mutations in P450scc, as we do in all other steroidogenic 
enzymes?' As P450scc is required for placental steroidogenesis, and placental progesterone is required to suppress uterine contractility to maintain pregnancy, we inferred that absence of $\mathrm{P} 450 \mathrm{scc}$ and placental steroidogenesis would lead to spontaneous abortion, so that P450scc deficiency would result in embryonic lethality [48]. This view appears to be consistent with two recent reports of the lipoid CAH phenotype in patients with partial deficiency of P450scc. One patient carried a de novo heterozygous mutation not found in either parent [49]; the other was a compound heterozygote, but one of the "mutations' was simply a polymorphism having no impact on P450scc catalysis [50]. In these cases, the lipoid $\mathrm{CAH}$ phenotype can again be attributed to a modification of the two-hit model of lipoid CAH [49]. Thus, unusual patients provide definitive tests of models formulated from observations from experiments in vitro.

\section{The Biochemistry of StAR}

StAR is a most unusual protein. It is initially synthesized as a $37-\mathrm{kD}$ a protein that is cleaved to a $30-\mathrm{kDa}$ form when it is imported into mitochondria. Cloning studies and analyses of DNA databases show that StAR is the first member of a new class of proteins that have so-called START (StAR-related lipid transfer) domains, which are structurally related to residues 62-285 of StAR [51-53]. The X-ray crystal structure of two of these proteins, N-218 MLN64 [54] and StarD4 [55], has been determined, showing that each has a helix-grip fold encompassing a hydrophobic pocket that appears to be able to bind a single molecule of cholesterol. While StAR/cholesterol binding curves also indicate that StAR binds a single cholesterol molecule [54], experiments with StAR-induced lipid transfer between liposomes show that each molecule of StAR can transfer several cholesterol molecules in vitro $[56,57]$ and experiments in vivo suggest that each molecule of StAR can promote the movement of hundreds of molecules of cholesterol from the outer mitochondrial membrane $(\mathrm{OMM})$ to the inner mitochondrial membrane (IMM) [58]. This fostered the view that StAR functions in the mitochondrial intramembranous space (IMS) to shuttle cholesterol from OMM to IMM. Furthermore, the cleavage of the $37-\mathrm{kDa}$ StAR to the $30-\mathrm{kDa}$ StAR, similarly to other mitochondrial proteins, led to the mistaken notion that the $37-\mathrm{kDa}$ form is a 'precursor' and the 30$\mathrm{kDa}$ protein is the 'mature' form. However, it is now clear that StAR's activity is determined by its cellular location, and not by its proteolytic cleavage status. Hence the 37-
$\mathrm{kDa}$ form is 'mature' (i.e. active) and the $30-\mathrm{kDa}$ form represents the first step in the intramitochondrial degradation of StAR [59]. Deleting the mitochondrial leader peptide prevents StAR from entering the mitochondria and confines it to the cytoplasm; yet this N-62 StAR molecule remains fully active [60], and is also able to transfer cholesterol to other membranes, such as the endoplasmic reticulum [61]. Thus, it appeared that StAR's mitochondrial leader peptide directed StAR's activity to the mitochondria and was confined to that organelle, preventing it from transferring cholesterol to other membranes, and that StAR's activity was confined to the OMM [62]. The aminoterminal domain of StAR (residues 63-193) is protease resistant, suggesting tight protein folding [63]. This would presumably slow mitochondrial import, prolonging contact with the OMM, and increasing activity. N-62 StAR undergoes a conformational change in acidic environments, both in solution and in synthetic membranes [63, 64]. This conformational change appears to foster association with the OMM, facilitating binding of OMM cholesterol for transfer to the IMM. However, until recently this view had been controversial.

Using novel fusion proteins that affix StAR to the OMM, confine it to the IMS, or affix it to the IMM, we have now proven that StAR acts exclusively on the OMM, and is wholly inactive in all other mitochondrial compartments [65]. By fusing StAR to a protein (Tom 20) that is a component of the OMM, we confined StAR to the cytoplasmic side of the OMM and prevented its mitochondrial entry, resulting in a dramatic increase in activity. This suggests that the level of StAR activity is proportional to the time it resides on the OMM. To test this, we built variants of StAR with altered mitochondrial leaders designed to either slow or speed its mitochondrial entry. Constructs designed for slow entry increased activity both in intact cells and in isolated mitochondria; constructs designed to speed entry similarly decreased activity. Using an in vitro cell-free transcription/translation system and in vitro assays of the kinetics of mitochondrial protein import, we could show that each construct either increased or decreased the speed of mitochondrial protein entry, as designed, and that the level of StAR activity was inversely proportional to its speed of entry [65]. Recent experiments have shown that only the carboxyl-terminal $\alpha$-helix of StAR interacts with the OMM [65a]. Thus, StAR acts exclusively on the OMM to facilitate the transfer of many molecules of cholesterol to the IMM. StAR then is imported into the mitochondria and cleaved to the $30-\mathrm{kDa}$ form. This $30-\mathrm{kDa}$ StAR protein is inactive, not because of the proteolytic 
cleavage but because of its location in the mitochondrial matrix from where it cannot reach the cytoplasmic aspect of the OMM [65].

\section{P450c17 - The Qualitative Regulator of Steroidogenesis}

Whereas the StAR/P450scc system is the rate-limiting and hormonally regulated step, and hence is the quantitative regulator of steroidogenesis, $\mathrm{P} 450 \mathrm{c} 17$ is the qualitative regulator that determines which class of steroids that would be produced [8]. When P450c17 is absent, such as in the adrenal zona glomerulosa, the products are $\mathrm{C} 21$ (21carbon) 17-deoxysteroids, such as aldosterone. When the $17 \alpha$-hydroxylase and 17,20 lyase activities of $\mathrm{P} 450 \mathrm{c} 17$ are present, $\mathrm{C} 19$ precursors of sex steroids are produced. Because all steroid hormones are made from the pregnenolone produced by $\mathrm{P} 450 \mathrm{scc}$, the presence or absence of each of the activities of $\mathrm{P} 450 \mathrm{c} 17$ directs this pregnenolone toward its final metabolic pathway. While all cytochrome P450 enzymes can catalyze multiple reactions on a single active site, $\mathrm{P} 450 \mathrm{c} 17$ is the only one described to date in which these multiple activities are differentially regulated by a physiologic process. Unlike P450scc, which is found in mitochondria, $\mathrm{P} 450 \mathrm{c} 17$ is found in the endoplasmic reticulum. These 'microsomal' P450 enzymes, which include all of the drug-metabolizing hepatic cytochrome P450 enzymes, receive electrons from NADPH via a flavoprotein intermediate called P450 oxidoreductase (POR).

\section{P450c17 - One Enzyme with Two Activities}

Until the 1980s, observations of human physiology led to the mistaken belief that $17 \alpha$-hydroxylase and 17,20 lyase were separate enzymes, regulated independently. The adrenals of young children make very little dehydroepiandrosterone (DHEA) until the onset of adrenarche and the development of the adrenal zona reticularis. Andrenarche begins at about age 6-8, is independent of the gonads or gonadotropins, and continues after the end of puberty, since serum DHEA and DHEA-S concentrations are highest between ages 25 and 30 [66-68]. This profound increase in adrenal DHEA synthesis proceeds without changes in the serum concentrations of cortisol and $\mathrm{ACTH}$ [66], and thus appears to involve selective induction of 17,20 lyase activity, while $17 \alpha$-hydroxylase activity, as indicated by the age-independent cortisol con- centrations, remains essentially unchanged. This phenomenon, adrenarche, is difficult to study, because it only occurs in large old-world primates [69, 70]. Searches for a hormonal trigger for adrenarche have been unsuccessful [71-73]. Early reports of familial, apparently autosomal recessive isolated 17,20 lyase deficiency, in which the patients had normal cortisol values and hence normal $17 \alpha-$ hydroxylase activity [74-76], appeared to confirm that $17 \alpha$-hydroxylase and 17,20 lyase were separate enzymes encoded by separate genes. However, biochemical studies with the pig [77-80] and guinea pig [81, 82] showed that a single protein, cytochrome P450c17, catalyzed both reactions on single active site, and nonsteroidogenic cells transfected with vectors that expressed bovine [83] or human [84] P450c17 acquired both $17 \alpha$-hydroxylase and 17,20 lyase activities. Accordingly, genetic studies showed that there was a single species of P450c17 mRNA that was identical in the human adrenal and gonad [85], because it was encoded by a single-copy gene [86] (now termed CYP17) on chromosome 10q24.3 [7, 87, 88]. Thus, although the transcriptional regulation of human P450c17 is of central importance [89-91], to regulate the amount of $\mathrm{P} 450 \mathrm{c} 17$ present, the differential regulation of the two activities of $\mathrm{P} 450 \mathrm{c} 17$ must lie at one or more points downstream from its gene. All present data now indicate that this regulation is mediated by several factors, all of which influence electron flow from NADPH via POR to P450c17 [92].

\section{Role of Redox Partners in Regulating 17,20 Lyase Activity}

Hall was first to note that POR is much more abundant in the porcine testis, which has a high ratio of lyase to hydroxylase activity, than in the porcine adrenal, which has low lyase activity $[93,94]$. Combining these proteins in vitro showed that POR was needed for both activities, and had suggested that cytochrome $b_{5}$ could selectively augment the 17,20 lyase reaction [93-95]. It had generally been thought that cytochrome $b_{5}$ can serve as an alternative electron transfer protein, taking the place of POR in certain circumstances [96, 97]. Transfection of nonsteroidogenic monkey kidney COS-1 cells with a vector expressing human $\mathrm{P} 450 \mathrm{c} 17$ permits the cells to catalyze 17,20 lyase activity that converts $17-\mathrm{OH}$ pregnenolone to DHEA, but not $17-\mathrm{OH}$ progesterone to androstenedione [84]. When these cells are cotransfected with a vector expressing human POR, conversion of $17-\mathrm{OH}$ pregnenolone to DHEA increases, but $17-\mathrm{OH}$ progester- 
one is not converted to androstenedione [98]. Thus, qualitative data obtained in whole living cells indicated that human P450c17 catalyzes 17,20 lyase activity only with $\Delta^{5}$ substrates, and that this activity could be augmented by excess POR.

To understand the enzymology of P450c17 in detail, we utilized yeast systems in which the endogenous yeast genes for POR or $b_{5}$ were disrupted, permitting rigorous kinetic analysis of the role of each potential redox partner on each of the four potential reactions of human P450c17 [99]. These data confirm that POR is required for both $17 \alpha$-hydroxylation and 17,20 lyase activity and that the 17,20 lyase reaction is much more severely impeded by low concentrations of POR than is the $17 \alpha$-hydroxylase reaction. Cytochrome $b_{5}$ selectively augments 17,20 lyase activity when POR is present, but $b_{5}$ alone cannot support catalysis. Apo- $b_{5}$, which is the cytochrome protein without its heme group, is as effective at promoting 17,20 lyase activity as holo- $b_{5}$ which has the heme group, indicating that $b_{5}$ augments the 17,20 lyase activity of $\mathrm{P} 450 \mathrm{c} 17$ as an allosteric facilitator, and not as an electron donor. The expression of $b_{5}$ in the adrenal is largely confined to the zona reticularis $[100,101]$ and this expression increases during adrenarche [102], so that adrenal levels of $\mathrm{b}_{5}$ correlate with DHEA secretion. Surprisingly, 17-OH progesterone is a poor substrate for human $\mathrm{P} 450 \mathrm{c} 17$. The $\mathrm{K}_{\mathrm{m}}$ of the 17,20 lyase reaction is 10 times higher, and the $\mathrm{V}_{\text {max }}$ is reduced to $30 \%$ when $\Delta^{4} 17-\mathrm{OH}$ progesterone is the substrate compared to the values with $\Delta^{5} 17-\mathrm{OH}$ pregnenolone. Thus, the 17,20 lyase action of human P450c17 is about 30 -fold greater with $\Delta^{5}$ substrates than with $\Delta^{4}$ substrates. As a result, most androstenedione is produced by the action of $3 \beta$-hydroxysteroid dehydrogenase on DHEA, and only minimal quantities derive from $17-\mathrm{OH}$ progesterone, so that most human sex steroid production is from DHEA.

\section{Isolated 17,20 Lyase Deficiency}

Several patients with apparent isolated 17,20 lyase deficiency were described in the 1970s and 1980s, but the demonstration that a single enzyme encoded by a single gene catalyzed both $17 \alpha$-hydroxylase and 17,20 lyase activities put the existence of such a disease in doubt. Further questions were raised when Waterman's group showed that a patient with apparent isolated 17,20 lyase deficiency in fact had P450c17 mutations that caused complete $17 \alpha$-hydroxylase deficiency [103]. No genetically and enzymologically proven cases of isolated 17,20 lyase deficiency had been reported until 1997, when we studied two patients from rural Brazil who had clinical and hormonal findings consistent with isolated 17,20 lyase deficiency [104].

DNA sequencing showed that each was homozygous for a different mutation; in one patient, the arginine at position 347 was replaced with histidine $(\mathrm{R} 347 \mathrm{H})$ and, in the other patient, the arginine at position 358 was replaced with glutamine (R358Q). Transfection of COS-1 cells with vectors expressing these P450c17 mutants showed that each retained only about $5 \%$ of normal 17,20 lyase activity but retained about $65 \%$ of normal $17 \alpha$-hydroxylase activity. Despite this loss of lyase activity, 17$\mathrm{OH}$ pregnenolone acted as a strictly competitive inhibitor of the hydroxylase reaction, showing that these mutations did not affect the active site [105]. However, the 17,20 lyase activity of these mutants could be partially restored by adding excess $b_{5}$, suggesting that they affect binding of redox partners and consequent electron transfer [105]. Molecular modeling of P450c17 based on the known Xray crystallographic structures of several bacterial cytochrome P450 enzymes showed that the two mutations altered the distribution of electrostatic charge on the surface of the P450c17 protein in the region that interacts with POR [106]. Thus, changing a single positive charge to neutral or to a negative charge partially decreased the ability of P450c17 to interact with POR, so that $17 \alpha$-hydroxylation was relatively unaffected, but 17,20 lyase activity was severely disrupted, in fashion very analogous to the persistence of $17 \alpha$-hydroxylase activity but the relative absence of 17,20 lyase activity when the concentrations of POR are low. Thus, isolated 17,20 lyase deficiency is an important 'site-directed mutagenesis experiment of nature' that identifies redox partner interactions as crucial regulators of 17,20 lyase activity.

\section{POR Deficiency}

A rare variant of 17,20 lyase deficiency seen in association with partial deficiency of steroid 21-hydroxylase was first described in 1985 by Peterson et al. [107] and is now understood in detail [108]. Mutations in the genes for P450c17 and P450c21 (steroid 21-hydroxylase) were sought but not found. In 1986, we suggested that this disorder was a deficiency of POR [109], but this seemed unlikely as POR knockout mice do not survive past the middle of fetal development $[110,111]$. Furthermore, most children with apparent combined $17 \alpha$-hydroxylase and 21-hydroxylase deficiencies also have the Antley-Bixler 
skeletal malformation syndrome (ABS), consisting of craniosynostosis, radioulnar or radiohumeral synostosis, and mid-face hypoplasia, and half also have genital anomalies. About half of the children with ABS have mutations in fibroblast growth factor receptor 2 (FGFR2), as do most patients with the Apert, Crouzon, Jackson-Weiss and Pfeiffer craniosynostosis syndromes, but the ABS patients who have FGFR2 mutations do not have abnormal steroidogenesis, and those who lack FGFR2 mutations have abnormal steroidogenesis [112]. The availability of the human POR gene sequence provided by the human genome project permitted the examination of the POR gene in this disorder. We found POR mutations in 3 children with $\mathrm{ABS}$ and abnormal steroidogenesis, and also in an adult woman with amenorrhea, hypertension, cystic ovaries and hormonal findings suggesting partial combined $17 \alpha$-hydroxylase and 21-hydroxylase deficiencies [113]. We found five different POR missense mutations, and tested the ability of each to receive electrons from NADPH and to donate them to both a test substrate (cytochrome c) and a real substrate (P450c17). There was substantially better phenotype/genotype correlation with the P450c17 assays than with the cytochrome c assays [113]. This indicates that POR mutants will donate electrons to different substrates with different efficiencies; thus, a POR mutant may severely affect some P450 enzymes but not others. As POR donates electrons to hepatic drug-metabolizing P450 enzymes, minor POR sequence variants may contribute to genetic variations in drug metabolism. The similarity between the hormonal phenotypes in POR deficiency and mutations in the POR (redox partner) binding site of P450c17 further underscores the crucial role of electron donation in regulating 17,20 lyase activity and hence regulating androgen synthesis. We recently reported a large series of 32 such patients, confirming and extending these observations [113a].

\section{Serine Phosphorylation of P450 Increases 17,20 Lyase Activity}

Radiolabeling studies of COS- 1 cells transfected with a human P450c17 expression vector or of untransfected human adrenal NCI-H295 cells [114], which express all human steroidogenic enzymes [115], showed that human P450c17 is a phosphoprotein [116]. This phosphorylation is rapidly induced by cAMP, occurs on serine and threonine but not on tyrosine residues, and increases the 17,20 lyase activity of P450c17. Conversely, dephosphor- ylation of microsomes containing P450c17 ablates 17,20 lyase activity without reducing $17 \alpha$-hydroxylase activity and without affecting steroid binding to the enzyme. The mechanism by which serine phosphorylation promotes 17,20 lyase activity is not yet known. Phosphorylated serine residues near the redox partner binding site may increase the affinity of $\mathrm{P} 450 \mathrm{c} 17$ for POR or $\mathrm{b}_{5}$ (or both), thus effectively increasing the flow of electrons to the $\mathrm{P} 450$. The kinase responsible for P450c17 serine phosphorylation has not been identified yet, but recent data indicate that the degree of phosphorylation in vivo is regulated by the counterbalancing actions of the kinase and protein phosphatase $2 \mathrm{~A}$, which in turn is regulated by phosphoprotein SET [117].

\section{Serine Phosphorylation, Adrenarche and the Polycystic Ovary Syndrome}

The polycystic ovary syndrome (PCOS) is a heterogenous disorder characterized by hirsutism, virilism, hyperandrogenism, menstrual irregularities, chronic anovulation, obesity, insulin resistance, acanthosis nigricans, high concentrations of LH and ovarian cysts. Hyperandrogenism and insulin resistance appear to be primary lesions, and the other findings are secondary events [118]. The hyperandrogenism in women with PCOS is of both ovarian and adrenal origin [119-122]. The adrenal hyperandrogenism of PCOS resembles an exaggerated form of adrenarche, and girls with premature adrenarche are more likely to develop PCOS [123, 124]. A gain-of-function disorder in the pathway leading to the serine/threonine phosphorylation of P450c17 could account for such increases in both adrenal and ovarian androgen secretion and an earlier age of adrenarche [116], but such mutations have not yet been reported. The hyperinsulism and insulin resistance of PCOS is at the level of insulin receptor signal transduction $[125,126]$. Serine phosphorylation of the $\beta$ chain of the insulin receptor interferes with the tyrosine phosphorylation of the receptor that normally follows binding of insulin [127-129]. Furthermore, some PCOS women appear to have insulin receptors in their fibroblasts that are hyperphosphorylated [130]. Thus, a gain-of-function mutation in a serine-threonine kinase or its signal transduction pathway might increase the serine hyperphosphorylation of both $\mathrm{P} 450 \mathrm{c} 17$ and the $\beta$ chain of the insulin receptor, thus accounting for both the hyperandrogenism and insulin resistance of PCOS with a single molecular lesion. 


\section{Conclusions}

Defects in the synthesis of DHEA cause deficiencies in the synthesis of androgens and estrogens. In the first stage, mutations in the StAR gene cause potentially lethal lipoid CAH. Defects in the cholesterol side chain cleavage enzyme, the second step, are rare. Defects in the third stage, 17-hydroxylation lead to hypertension and female sexual infantilism. Defects in the final stage of DHEA synthesis, 17,20 lyase activity, are due to disorders of electron transfer to $\mathrm{P} 450 \mathrm{c} 17$, including mutations in POR. Of these, the defect in StAR is common among Palestinian Arabs and in Eastern Arabia.

\section{References}

- 1 Fardella CE, Miller WL: Molecular biology of mineralocorticoid metabolism. Ann Rev Nutrition 1996;16:443-470.

2 Miller WL, Chrousos GP: The adrenal cortex; in Felig P, Frohman L (eds): Endocrinology and Metabolism, ed 4. New York, McGrawHill, 2001, pp 387-524.

-3 Stocco DM, Clark BJ: Regulation of the acute production of steroids in steroidogenic cells. Endocr Rev 1996;17:221-244.

-4 Miller WL: Congenital lipoid adrenal hyperplasia: The human knockout of the steroidogenic acute regulatory protein. J Mol Endocrinol 1997; 19:227-240.

$\checkmark 5$ Chung B, Matteson KJ, Voutilainen R, Mohandas TK, Miller WL: Human cholesterol side-chain cleavage enzyme, P450scc: cDNA cloning, assignment of the gene to chromosome 15 , and expression in the placenta. Proc Natl Acad Sci USA 1986;83:8962-8966.

-6 Morohashi K, Sogawa K, Omura T, Fujii-Kuriyama Y: Gene structure of human cytochrome P-450(scc), cholesterol desmolase. J Biochem 1987;101:879-887.

7 Sparkes RS, Klisak I, Miller WL: Regional mapping of genes encoding human steroidogenic enzymes: P450scc to 15q23-q24, adrenodoxin to $11 \mathrm{q} 22$; adrenodoxin reductase to 17q24-q25; and P450c17 to 10q24-q25. DNA Cell Biol 1991;10:359-365.

8 Miller WL: Molecular biology of steroid hormone synthesis. Endocr Rev 1988;9:295-318.

9 Moore CCD, Brentano ST, Miller WL: Human $\mathrm{P} 450$ scc gene transcription is induced through cyclic AMP and repressed by $12-O$-tetradecanoylphorbol-13-acetate and A23187 by independent cis-elements. Mol Cell Biol 1990;10: 6013-6023.

10 Moore CCD, Hum DW, Miller WL: Identification of positive and negative placental-specific basal elements and a cyclic adenosine 3',5'monophosphate response element in the human gene for P450scc. Mol Endocrinol 1992; 6:2045-2058.

11 Huang N, Miller WL: Cloning of factors related to HIV-inducible LBP proteins that regulate steroidogenic factor-1-independent human placental expression of the cholesterol side-chain cleavage enzyme, P450scc. J Biol Chem 2000;275:2852-2858.
12 Voutilainen R, Tapanainen J, Chung B, Matteson KJ, Miller WL: Hormonal regulation of P450sec (20,22 desmolase) and P450c17 (17 $\alpha$ hydroxylase/17,20 lyase) in cultured human granulosa cells. J Clin Endocrinol Metab 1986; 63:202-207.

13 DiBlasio AM, Voutilainen R, Jaffe RB, Miller WL: Hormonal regulation of mRNA for P450scc (cholesterol side-chain cleavage enzyme) and P450c17 (17 $\alpha$-hydroxylase/17,20 lyase) in cultured human fetal adrenal cells. $\mathrm{J}$ Clin Endocrinol Metab 1987;65:170-175.

-14 Picado-Leonard J, Voutilainen R, Kao L, Chung B, Strauss JF 3rd, Miller WL: Human adrenodoxin: Cloning of three cDNAs and cycloheximide enhancement in JEG-3 cells. J Biol Chem 1988;263:3240-3244.

15 Solish S, Picado-Leonard J, Morel Y, Kuhn RW, Mohandas TK, Hanukoglu I, Miller WL: Human adrenodoxin reductase: Two mRNAs encoded by a single gene on chromosome 17 cen $\rightarrow$ q 25 are expressed in steroidogenic tissues. Proc Natl Acad Sci USA 1988;85:71047108.

16 Chang C-Y, Wu D-A, Lai C-C, Miller WL, Chung B: Cloning and structure of the human adrenodoxin gene. DNA 1988;7:609-615.

17 Lin D, Shi Y, Miller WL: Cloning and sequence of the human adrenodoxin reductase gene. Proc Natl Acad Sci USA 1990;87:85168520.

18 Black SM, Harikrishna JA, Szklarz GD, Miller WL: The mitochondrial environment is required for activity of the cholesterol side-chain cleavage enzyme, cytochrome P450scc. Proc Natl Acad Sci USA 1994;91:7247-7251.

19 Stone D, Hechter O: Studies on ACTH action in perfused bovine adrenals: Aspects of progesterone as an intermediary in cortico-steroidogenesis. Arch Biochem Biophys 1955;54:121128.

20 Ferguson JJ: Protein synthesis and adrenocorticotropin responsiveness. J Biol Chem 1963; 238:2754-2759.

21 Garren LD, Ney RL, Davis WW: Studies on the role of protein synthesis in the regulation of corticosterone production by ACTH in vivo. Proc Natl Acad Sci USA 1965;53:1443-1450.

22 Garren LD, Davis WW, Crocco RM: Puromycin analogs: Action of adrenocorticotropic hormone and the role of glycogen. Science 1966; 152:1386-1388.
23 Pon LA, Orme-Johnson NR: Acute stimulation of steroidogenesis in corpus luteum and adrenal cortex by peptide hormones. J Biol Chem 1986;261:6594-6599.

24 Epstein LF, Orme-Johnson NR: Regulation of steroid hormone biosynthesis. Identification of precursors of a phosphoprotein targeted to the mitochondrion in stimulated rat adrenal cortex cells. J Biol Chem 1991;266:19739-19745.

25 Stocco DM, Sodeman TC: The 30-kDa mitochondrial protein induced by hormone stimulation in MA-10 mouse Leydig tumor cells are processed from larger precursors. J Biol Chem 1991;266:19731-19738.

26 Clark BJ, Wells J, King SR, Stocco DM: The purification, cloning and expression of a novel luteinizing hormone-induced mitochondrial protein in MA-10 mouse Leydig tumor cells. Characterization of the steroidogenic acute regulatory protein (StAR). J Biol Chem 1994; 269:28314-28322.

27 Lin D, Sugawara T, Strauss JF 3rd, Clark BJ, Stocco, DM, Saenger P, Rogol A, Miller WL: Role of steroidogenic acute regulatory protein in adrenal and gonadal steroidogenesis. Science 1995;267:1828-1831.

28 Saenger P, Klonari Z, Black SM, Compagnone $\mathrm{N}$, Mellon SH, Fleischer A, Abrams CAL, Shackleton CHL, Miller WL: Prenatal diagnosis of congenital lipoid adrenal hyperplasia. J Clin Endocrinol Metab 1995;80:200-205.

-29 Tee MK, Lin D, Sugawara T, Holt JA, Guiguen Y, Buckingham B, Strauss JF 3rd, Miller WL: $\mathrm{T} \rightarrow \mathrm{A}$ transversion $11 \mathrm{bp}$ from a splice acceptor site in the gene for steroidogenic acute regulatory protein causes congenital lipoid adrenal hyperplasia. Hum Mol Genet 1995;4:2299-2305.

30 Kirkland RT, Kirkland JL, Johnson CM, Horning MG, Librik L, Clayton GW: Congenital lipoid adrenal hyperplasia in an eight-yearold phenotypic female. J Clin Endocrinol Metab 1973;36:488-496.31.

- 31 Hauffa BP, Miller WL, Grumbach MM, Conte FA, Kaplan SL: Congenital adrenal hyperplasia due to deficient cholesterol side-chain cleavage activity $(20,22$ desmolase $)$ in a patient treated for 18 years. Clin Endocrinol 1985;23: 481-493.

32 Bose HS, Sugawara T, Strauss JF 3rd, Miller WL: The pathophysiology and genetics of congenital lipoid adrenal hyperplasia. N Engl J Med 1996;335:1870-1878. 
-33 Furukawa A, Miyatake A, Ohnishi T, Ichikawa Y: Steroidogenic acute regulatory protein (StAR) transcripts constituitively in the adult rat central nervous system: Colocalization of StAR, cytochrome P450scc (CYP XIA1) and $3 \beta$-hydroxysteroid dehydrogenase in the rat brain. J Neurochem 1998;71:2231-2238.

- 34 Kimoto T, Tsurugizawa T, Ohta Y, Makino J, Tamura H, Hojo Y, Takata N, Kawato S: Neurosteroid synthesis by cytochrome p450containing systems localized in the rat brain hippocampal neurons: N-methyl- $D$-aspartate and calcium-dependent synthesis. Endocrinology 2001;142:3578-3589.

- 35 King SR, Manna PR, Ishii T, Syapin PJ, Ginsberg SD, Wilson K, Walsh LP, Parker KL, Stocco DM, Smith RG, Lamb DJ: An essential component in steroid synthesis, the steroidogenic acute regulatory protein, is expressed in discrete regions of the brain. J Neurosci 2002; 22:10613-10620.

-36 Compagnone NA, Mellon, SH: Neurosteroids: Biosynthesis and function of these novel neuromodulators. Front Neuroendocrinol 2000; 21:1-56.

- 37 Nakae J, Tajima T, Sugawara T, Arakane F, Hanaki K, Hotsubo T, Igarashi N, Igarashi $\mathrm{Y}$, Ishii T, Koda N, Kondo T, Kohno H, Nakagawa Y, Tachibana K, Takeshima Y, Tsubouchi K, Strauss JF 3rd, Fujieda K: Analysis of the steroidogenic acute regulatory protein (StAR) gene in Japanese patients with congenital lipoid adrenal hyperplasia. Hum Mol Genet 1997;6:571-576.

- 38 Voutilainen R, Miller WL: Developmental expression of genes for the steroidogenic enzymes P450scc (20,22 desmolase), P450c17 (17 $\alpha$-hydroxylase/17,20 lyase) and P450c21 (21-hydroxylase) in the human fetus. J Clin Endocrinol Metab 1986;63:1145-1150.

- 39 Bose HS, Pescovitz OH, Miller WL: Spontaneous feminization in a $46, \mathrm{XX}$ female patient with congenital lipoid adrenal hyperplasia caused by a homozygous frame-shift mutation in the steroidogenic acute regulatory protein. $\mathrm{J}$ Clin Endocrinol Metab 1997;82:1511-1515.

-40 Fujieda K, Tajima T, Nakae J, Sageshima S, Tachibana K, Suwa S, Sugawara T, Strauss JF 3rd: Spontaneous puberty in $46, \mathrm{XX}$ subjects with congenital lipoid adrenal hyperplasia. J Clin Invest 1997;99:1265-1271.

-41 Caron KM, Soo S-C, Wetsel WC, Stocco DM, Clark BJ, Parker KL: Targeted disruption of the mouse gene encoding steroidogenic acute regulatory protein provides insights into congenital lipoid adrenal hyperplasia. Proc Natl Acad Sci USA 1997;94:11540-11545.

- 42 Hasegawa T, Zhao L, Caron KM, Majdic G, Suzuki T, Shizawa S, Sasano H, Parker KL: Developmental roles of the steroidogenic acute regulatory protein (StAR) as revealed by StAR knockout mice. Mol Endocrinol 2000; 14 : 1462-1471.

43 Bose HS, Sato S, Aisenberg J, Shalev SA, Matsuo N, Miller WL: Mutations in the steroidogenic acute regulatory protein (StAR) in six patients with congenital lipoid adrenal hyperplasia. J Clin Endocrinol Metab 2000;85: 3636-3639.
44 Yoo HW, Kim GH: Molecular and clinical characterization of Korean patients with congenital lipoid adrenal hyperplasia. J Pediatr Endocrinol Metab 1998;11:707-711.

-45 Chen X, Baker BY, Abduljabbar MA, Miller WL: A genetic isolate of congenital lipoid adrenal hyperplasia with atypical clinical features. J Clin Endocrinol Metab 2005;90:835840.

46 Matteson KJ, Chung B, Urdea MS, Miller WL: Study of cholesterol side-chain cleavage $(20,22$ desmolase) deficiency causing congenital lipoid adrenal hyperplasia using bovine-sequence P450scc oligodeoxyribonucleotide probes. Endocrinology 1986;118:1296-1305.

47 Lin D, Gitelman SE, Saenger P, Miller WL: Normal genes for the cholesterol side chain cleavage enzyme, P450scc, in congenital lipoid adrenal hyperplasia. J Clin Invest 1991;88: 1955-1962.

48 Miller WL: Why nobody has P450sce (20,22 desmolase) deficiency (letter to the editor). J Clin Endocrinol Metab 1998;83:1399-1400.

-49 Tajima T, Fujieda K, Kouda N, Nakae J, Miller WL: Heterozygous mutation in the cholesterol side chain cleavage enzyme (P450scc) gene in a patient with $46, \mathrm{XY}$ sex reversal and adrenal insufficiency. J Clin Endocrinol Metab 2001;86:3820-3825.

50 Katsumata N, Ohtake M, Hojo T, Ogawa E, Hara T, Sato N, Tanaka T: Compound heterozygous mutations in the cholesterol side-chain cleavage enzyme gene (CYP11A) cause congenital adrenal insufficiency in humans. J Clin Endocrinol Metab 2002;87:3808-3813.

51 Ponting CP, Aravind L: START: A lipid-binding domain in StAR, HD-ZIP and signaling proteins. Trends Biochem Sci 1999;24:130132.

-52 Iyer LM, Koonin EV, Aravind L: Adaptations of the helix-grip fold for ligand binding and catalysis in the START domain superfamily. Proteins 2001;43:134-144.

53 Soccio RE, Breslow JL: StAR-related lipid transfer (START) proteins: Mediators of intracellular lipid metabolism. J Biol Chem 2003; 278:22183-22186.

54 Tsujishita Y, Hurley JH: Structure and lipid transport mechanism of a StAR-related domain. Nat Struct Biol 2000;7:408-414.

55 Romanowski MJ, Soccio RE, Breslow JL, Burley SK: Crystal structure of the Mus musculus cholesterol-regulated START protein 4 (StarD4) containing a StAR-related lipid transfer domain. Proc Natl Acad Sci USA 2002;99: 6949-6954.

-56 Tuckey RC, Headlam MJ, Bose HS, Miller WL: Transfer of cholesterol between phospholipid vesicles mediated by the steroidogenic acute regulatory protein (StAR). J Biol Chem 2002;277:47123-47128.

57 Tuckey RC, Bose HS, Czerwionka I, Miller WL: Molten globule structure and steroidogenic activity of N-218 MLN64 in human placental mitochondria. Endocrinology 2004; 145 : 1700-1707.
58 Artemenko I, Zhao D, Hales DB, Hales KH, Jefcoate CR: Mitochondrial processing of newly synthesized steroidogenic acute regulatory protein (StAR), but not total StAR, mediates cholesterol transfer to cytochrome P450 side chain cleavage enzyme in adrenal cells. J Biol Chem 2001;276:46583-46596.

59 Granot Z, Geiss-Frielander R, MelamedBrook N, Eimerl S, Timberg R, Weiss AM, Hales DB, Stocco DM, Orly J: Proteolysis of normal and mutated steroidogenic acute regulatory proteins in the mitochondria: The fate of unwanted proteins. Mol Endocrinol 2003; 17:2461-2476.

60 Arakane F, Sugawara T, Nishino H, Liu Z, Holt JA, Pain D, Stocco DM, Miller WL, Strauss JF 3rd: Steroidogenic acute regulatory protein (StAR) retains activity in the absence of its mitochondrial targeting sequence: Implications for the mechanism of StAR action. Proc Natl Acad Sci USA 1996;93:1373113736.

61 Kallen CB, Billheimer JT, Summers SA, Staybrook SE, Lewis M, Strauss JF 3rd: Steroidogenic acute regulatory protein (StAR) is a sterol transfer protein. J Biol Chem 1998;273: 26285-26288.

-62 Miller WL, Strauss JF 3rd: Molecular pathology and mechanism of action of the steroidogenic acute regulatory protein, StAR. J Steroid Biochem Mol Biol 1999;69:131-141.

-63 Bose HS, Whittal RM, Baldwin MA, Miller WL: The active form of the steroidogenic acute regulatory protein, StAR, appears to be a molten globule. Proc Natl Acad Sci USA 1999;9: 7250-7255.

64 Christinsen K, Bose HS, Harris FM Miller WL, Bell JD: Binding of StAR to synthetic membranes suggests an active molten globule. J Biol Chem 2001;276:17044-17051.

65 Bose, HS, Lingappa VR, Miller WL: Rapid regulation of steroidogenesis by mitochondrial protein import. Nature 2002;417:87-91.

65a Yaworsky DC, Baker BY, Bose HS, Best KB, Jensen LB, Bell JD, Baldwin MA, Miller WL: $\mathrm{pH}$-dependent interaction of the carboxyl-terminal helix of steroidogenic acute regulatory protein with synthetic membranes. J Biol Chem 2005;280:2045-2054.

- 66 Apter D, Pakarinen A, Hammond GL, Vihko R: Adrencortical function in puberty. Cortisol and DHEA in girls and boys. Acta Paediatr Scand 1979;68:599-604.

67 Sklar CA, Kaplan SL, Grumbach MM: Evidence for dissociation between adrenarche and gonadarche: Studies in patients with idiopathic precocious puberty, gonadal dysgenesis, isolated gonadotropin deficiency, and constitutionally delayed growth and adolescence. $\mathrm{J}$ Clin Endocrinol Metab 1980;51:548-556.

-68 Orentreich N, Brind JL, Rizer RL, Vogelman $\mathrm{JH}$ : Age changes and sex differences in serum dehydroepiandrosterone sulfate concentrations throughout adulthood. J Clin Endocrinol Metab 1984;59:551-555.

69 Cutler GB, Glenn M, Bush M, Hodgen GD, Graham CE, Loriaux DL: Adrenarche: A survey of rodents, domestic animals and primates. Endocrinology 1978;103:2112-2118. 
70 Arlt W, Martens JWM, Song M, Wang JT, Auchus RJ, Miller WL: Molecular evolution of adrenarche: Structural and functional analysis of P450c17 from four primate species. Endocrinology 2002;143:4665-4672.

71 Mellon SH, Shively JE, Miller WL: Human proopiomelanocortin (79-96), a proposed androgen stimulatory hormone, does not affect steroidogenesis in cultured human fetal adrenal cells. J Clin Endocrinol Metab 1991;72: 19-22.

72 Penhoat A, Sanchez P, Jaillard C, Langlois D, Begeot M, Saez JM: Human proopiomelanocortin (79-96), a proposed cortical androgen stimulating hormone, does not affect steroidogenesis in cultured human adult adrenal cells. J Clin Endocrinol Metab 1991;72:23-26.

73 Miller WL: The molecular basis of premature adrenarche: An hypothesis. Acta Paediatr 1999;88(suppl 433):60-66.

-74 Zachmann M, Vollmin JA, Hamilton W, Prader A: Steroid 17,20 desmolase deficiency: A new cause of male pseudohermaphroditism. Clin Endocrinol 1972;1:369-385.

-75 Goebelsmann U, Zachmann M, Davajan V, Israel R, Mestman JH, Mishell DR: Male pseudohermaphroditism consistent with 17,20desmolase deficiency. Gynecol Invest 1976;7: 138-156.

-76 Forest MG, Lecornu M, Peretti E: Familial male pseudohermaphroditism due to 17,20 desmolase deficiency. In vivo endocrine studies. J Clin Endocrinol Metab 1980;50:826833.

77 Nakajin S, Shively JE, Yuan P, Hall PF: Microsomal cytochrome P-450 from neonatal pig testis: Two enzymatic activities (17 $\alpha$-hydroxylase and C17,20-lyase) associated with one protein. Biochemistry 1981;20:4037-4042.

78 Nakajin S, Hall PF: Microsomal cytochrome P-450 from neonatal pig testis. Purification and properties of a $\mathrm{C}_{21}$ steroid side-chain cleavage system $\left(17 \alpha\right.$-hydroxylase- $\mathrm{C}_{17,20}$ lyase). J Biol Chem 1981;256:3871-3876.

79 Nakajin S, Hall PF: Testicular microsomal cytochrome $\mathrm{P} 450$ for $\mathrm{C}_{21}$ steroid side-chain cleavage. J Biol Chem 1981;256:6134-6139.

-80 Nakajin S, Shinoda M, Haniu M, Shively JE, Hall PF: $C_{21}$ steroid side-chain cleavage enzyme from porcine adrenal microsomes. Purification and characterization of the $17 \alpha$-hydroxylase $/ \mathrm{C}_{17,20}$ lyase cytochrome $\mathrm{P}-450$. J Biol Chem 1984;259:3971-3976.

-81 Kominami S, Shinzawa S, Takemori S: Purification and some properties of cytochrome P450 for steroid $17 \alpha$-hydroxylation and $C_{17,20}$ bond cleavage from guinea pig adrenal microsomes. Biochem Biophys Res Commun 1982; 109:916-921.

-82 Suhara K, Fujimura Y, Shiroo M, Katagiri M: Multiple catalytic properties of the purified and reconstituted cytochrome P-450 (P450 sccII) system of pig testis microsomes. J Biol Chem 1984;259:8729-8736.

-83 Zuber MX, Simpson ER, Waterman MR: Expression of bovine 17 $\alpha$-hydroxylase cytochrome P450 cDNA in non-steroidogenic (COS-1) cells. Science 1986;234:1258-1261.
84 Lin D, Harikrishna JA, Moore CCD, Jones KL, Miller WL: Missense mutation $\operatorname{Ser}^{106} \rightarrow$ Pro causes $17 \alpha$-hydroxylase deficiency. J Biol Chem 1991;266:15992-15998.

85 Chung B, Picado-Leonard J, Haniu M, Bienkowski M, Hall PF, Shivley JE, Miller WL: Cytochrome P450c17 (steroid 17 $\alpha$-hydroxylase/17,20 lyase): Cloning of human adrenal and testis cDNAs indicates the same gene is expressed in both tissues. Proc Natl Acad Sci USA 1987;84:407-411.

86 Picado-Leonard J, Miller WL: Cloning and sequence of the human gene encoding P450c17 (steroid 17 $\alpha$-hydroxylase/17,20 lyase): Similarity to the gene for P450c21. DNA 1987;6: 439-448.

-87 Matteson KJ, Picado-Leonard J, Chung B, Mohandas TK, Miller WL: Assignment of the gene for adrenal P450c17 (17 $\alpha$-hydroxylase/17,20 lyase) to human chromosome 10. J Clin Endocrinol Metab 1986;63:789-791.

88 Fan YS, Sasi R, Lee C, Winter JSD, Waterman MR, Lin CC: Localization of the human CYP17 gene (cytochrome P450 17 $\alpha$ ) to 10q24.3 by fluorescence in situ hybridization and simultaneous chromosome banding. Genomics 1992;14:1110-1111.

89 Brentano ST, Picado-Leonard J, Mellon SH, Moore CCD, Miller WL: Tissue-specific, cyclic adenosine 3',5'-monophosphate-induced, and phorbol ester-repressed transcription from the human P450c17 promoter in mouse cells. Mol Endocrinol 1990;4:1972-1979.

-90 Lin CJ, Martens JWM, Miller WL: NF-1c, Sp 1 , and $\mathrm{Sp} 3$ are essential for transcription of the human gene for $\mathrm{P} 450 \mathrm{c} 17$ (steroid $17 \alpha$-hydroxylase/17,20 lyase) in human adrenal NCIH295A cells. Mol Endocrinol 2001;15:12771293.

91 Flück CE, Miller WL: GATA-4 and GATA-6 modulate tissue specific transcription of the human gene for P450c17. Mol Endocrinol 2004; 18:1144-1157.

92 Miller WL, Auchus RJ, Geller DH: The regulation of 17,20 lyase activity. Steroids 1997;62: 133-142.

93 Onoda M, Hall PF: Cytochrome bs stimulates purified testicular microsomal cytochrome P450 $\left(\mathrm{C}_{21}\right.$ side-chain cleavage). Biochem Biophys Res Commun 1982;108:454-460.

-94 Yanagibashi K, Hall PF: Role of electron transport in the regulation of the lyase activity of C-21 side-chain cleavage P450 from porcine adrenal and testicular microsomes. J Biol Chem 1986;261:8429-8433.

-95 Kominami S, Ogawa N, Morimune R, Huang DY, Takemori S: The role of cytochrome $b_{5}$ in adrenal microsomal steroidogenesis. J Steroid Biochem Mol Biol 1992;42:57-64.

96 Tamburini PP, Gibson GG: Thermodynamic studies of the protein-protein interactions between cytochrome P-450 and cytochrome $b_{5} . \mathrm{J}$ Biol Chem 1983;258:13444-13452.
\$97 Guengerich FP, Martin M, Beaune P, Kremers P, Wolff T, Waxman D: Characterization of rat and human liver microsomal cytochrome P-450 forms involved in nifedipine oxidation, a prototype for genetic polymorphism in oxidative drug metabolism. J Biol Chem 1986;261:5051-5060.

98 Lin D, Black SM, Nagahama Y, Miller WL: Steroid $17 \alpha$-hydroxylase and 17,20 lyase activities of P450c17: Contributions of serine $^{106}$ and P450 reductase. Endocrinology 1993;132:2498-2506.

-99 Auchus RJ, Lee TC, Miller WL: Cytochrome $b_{5}$ augments the 17,20 lyase activity of human $\mathrm{P} 450 \mathrm{c} 17$ without direct electron transfer. J Biol Chem 1998;273:3158-3165.

100 Yanase T, Sasano H, Yubisui T, Sakai Y, Takayanagi R, Nawata H: Immunohistochemical study of cytochrome $b_{5}$ in the human adrenal gland and in adrenocortical adenomas from patients with Cushing syndrome. Endocr J 1998;45:89-95.

101 Mapes S, Corbin C, Tarantal A, Conley A: The primate adrenal zona reticularis is defined by expression of cytochrome $b_{5}, 17 \alpha$ hydroxylase/17,20-lyase cytochrome $\mathrm{P} 450$ (P450c17) and NADPH-cytochrome P450 reductase (reductase) but not $3 \beta$-hydroxysteroid dehydrogenase $/ \delta^{5-4}$ isomerase (3 $\beta$-HSD). J Clin Endocrinol Metab1999; 84:33823385.

102 Suzuki T, Sasano H, Takeyama J, Kaneko C, Freije WA, Carr BR, Rainey WE: Developmental changes in steroidogenic enzymes in human postnatal adrenal cortex: Immunohistochemical studies. Clin Endocrinol 2000;53: 739-747.

103 Yanase T, Waterman MR, Zachmann M, Winter JSD, Simpson ER, Kagimoto M: Molecular basis of apparent isolated 17,20 lyase deficiency: Compound heterozygous mutations in the C-terminal region $(\operatorname{Arg}(496) \rightarrow$ Cys, $\mathrm{Gln}(461) \rightarrow$ Stop) actually cause combined $17 \alpha$-hydroxylase/17,20 lyase deficiency. Biochim Biophys Acta 1992;1139:275-279.

104 Geller DH, Auchus RJ, Mendonça BB, Miller WL: The genetic and functional basis of isolated 17,20 lyase deficiency. Nat Genet 1997; 17:201-205.

105 Geller DH, Auchus RJ, Miller WL: P450c17 mutations R347H and R358Q selectively disrupt 17,20-lyase activity by disrupting interactions with P450 oxidoreductase and cytochrome b5. Mol Endocrinol 1999;13: 167-175.

106 Auchus RJ, Miller WL: Molecular modeling of human P450c17 (17 $\alpha$-hydroxylase/17,20lyase): Insights into reaction mechanisms and effects of mutations. Mol Endocrinol 1999; 13:1169-1182.

107 Peterson RE, Imperato-McGinley J, Gautier T, Shackleton C: Male pseudohermaphroditism due to multiple defects in steroid biosynthetic microsomal mixed-function oxidases. A new variant of congenital adrenal hyperplasia. N Engl J Med 1985;313:11821191. 
108 Miller WL: P450 oxidoreductase deficiency. A new disorder of steroidogenesis with multiple clinical manifestations. Trends Endocrinol Metab 2004 15:311-315.

109 Miller WL: Congenital adrenal hyperplasia (letter to editor). N Engl J Med 1986;314: 1321-1322.

110 Shen AL, O'Leary KA, Kasper CB: Association of multiple developmental defects and embryonic lethality with loss of microsomal NADPH-cytochrome P450 oxidoreductase. J Biol Chem 2002;277:6536-6541.

$\checkmark 11$ Otto DME, Henderson DJ, Carrie D, Davey M, Gunderson TE, Blomhoff R, Adams RH, Tickle C, Wolf CR: Identification of novel roles of they cytochrome P450 system in early embryogenesis: Effects on vasculogenesis and retinoic acid homeostatis. Mol Cell Biol 2003;23:6103-6116.

112 Reardon W, Smith A, Honour JW, Hindmarsh P, Das D, Rumsby G, Nelson I, Malcolm S, Ades L, Sillence D, Kumar D, DeLozier-Blanchet C, McKee S, Kelly T, McKeehan WL, Baraitser M, Winter RM: Evidence for digenic inheritance in some cases of Antley-Bixler syndrome? J Med Genet 2000;37:26-32.

$\checkmark 113$ Flück CE, Tajima T, Pandey AV, Arlt W, Okuhara K, Verge CF, Jabs EW, Mendonca BB, Fujieda K, Miller WL: Mutant P450 oxidoreductase causes disordered steroidogenesis with and without Antley-Bixler syndrome. Nature Genet 2004;36:228-230.

113a Huang N, Pandey AV, Agrawal V, Reardon W, Lapunzina PD, Mowat D, Jabs EW, Van Vliet G, Sack J, Flück CE, Miller WL: Diversity and function of mutations in P450 oxidoreductase in patients with Antley-Bixler syndrome and disordered steroidogenesis. Am J Hum Genet 2005;76:729-749.
114 Gazdar AF, Oie HK, Shackleton CH, Chen TR, Triche TJ, Myers CE, Chrousos GP, Brennan MF, Stein CA, LaRocca RV: Establishment and characterization of a human adrenocortical carcinoma cell line that expresses multiple pathways of steroid biosynthesis. Cancer Res 1990;50:5488-5496.

115 Staels B, Hum DW, Miller WL: Regulation of steroidogenesis in NCI-H295 cells: A cellular model of the human fetal adrenal. Mol Endocrinol 1993; 7:423-433.

116 Zhang L, Rodriguez H, Ohno S, Miller WL: Serine phosphorylation of human P450c17 increases 17,20 lyase activity: Implications for adrenarche and for the polycystic ovary syndrome. Proc Natl Acad Sci USA 1995;92: 10619-10623.

117 Pandey AV, Mellon SH, Miller WL: Protein phosphatase $2 \mathrm{~A}$ and phosphoprotein SET regulate androgen production by $\mathrm{P} 450 \mathrm{c} 17$. J Biol Chem 2003;278:2837-2844.

118 Dunaif A: Hyperandrogenic anovulation (PCOS): A unique disorder of insulin action associated with an increased risk of non-insulin-dependent diabetes mellitus. Am J Med 1995;98(suppl 1A):33S-39S.

119 Lachelin GCL, Barnett M, Hopper BR, Brink G, Yen SSC: Adrenal function in normal women and women with the polycystic ovary syndrome. J Clin Endocrinol Metab 1979;49: 840-848.

120 Lucky AW, Rosenfield RL, McGuire J, Rudy S, Helke J: Adrenal androgen hyperresponsiveness to ACTH in women with acne and/or hirsutism: Adrenal enzyme defects and exaggerated adrenarche. J Clin Endocrinol Metab 1986;62:840-848.

121 Ibañez L, Potau N, Zampolli M, Prat N, Gussinye M, Saenger P, Vicens-Clavet E, Carrascosa E: Source localization of androgen excess in adolescent girls. J Clin Endocrinol Metab 1994;79:1778-1784.

122 Ehrmann DA, Barnes RB, Rosenfield RL: Polycystic ovary syndrome as a form of functional ovarian hyperandrogenism due to dysregulation of androgen secretion. Endocr Rev $1995 ; 16: 322-353$
123 Ibañez L, Potau N, Virdis R, Zampolli M, Terzi C, Gussinyé M, Carrascosa A, VicensCalvet E: Postpubertal outcome in girls diagnosed of premature pubarche during childhood: Increased frequency of functional ovarian hyperandrogenism. J Clin Endocrinol Metab 1993;76:1599-1603.

124 Oppenheimer E, Linder B, DiMartino-Nardi $\mathrm{J}$ : Decreased insulin sensitivity in prepubertal girls with premature adrenarche and acanthosis nigricans. J Clin Endocrinol Metab 1995;80:614-618.

125 Dunaif A, Segal K, Futterweit W, Dobrjansky A: Profound peripheral insulin resistance, independent of obesity, in the polycystic ovary syndrome. Diabetes 1989;38:1165-1174.

126 Ciaraldi TP, El-Roeiy A, Madar Z, Reichart D, Olefsky JM, Yen SCC: Cellular mechanisms of insulin resistance in polycystic ovarian syndrome. J Clin Endocrinol Metab 1992; 75:577-583.

127 Bollag G, Roth R, Beaudoin J, MochleyRosen D, Koshland D Jr: Protein kinase C directly phosphorylates the insulin receptor in vitro and reduces its protein-tyrosine kinase activity. Proc Natl Acad Sci USA 1986; 83:5822-5824.

128 Stadtmauer L, Rosen OM: Increasing the cAMP content of IM-9 cells alters the phosphorylation state and protein kinase activity of the insulin receptor. J Biol Chem 1986; 261:3402-3407.

129 Takayama S, White MF, Kahn CR: Phorbol ester-induced serine phosphorylation of the insulin receptor decreases its tyrosine kinase activity. J Biol Chem 1988;263:3440-3447.

130 Dunaif A, Xia J, Book C-B, Schenker E, Tang $\mathrm{Z}$ : Excessive insulin receptor serine phosphorylation in cultured fibroblasts and in skeletal muscle. J Clin Invest 1995;96:801810 